7. Reprod. Fert. (1969) 18, 305-316

\title{
REPRODUCTION IN THE FERRET (MUSTELA FURO)
}

\section{CHANGES FOLLOWING OVARIEGTOMY DURING EARLY PREGNANGY}

\author{
G. DALE BUGHANAN*
}

Department of Anatomy, University of Tennessee Medical Units, Memphis, Tennessee

(Received 19th March 1968, revised 13th May 1968)

Summary. Bilateral ovariectomy before Day 10 post coitum (p.c.) prevented implantation of ferret blastocysts. However, blastocysts survived for about a week beyond the normal time of implantation and although the zonae pellucidae were not shed, many underwent a marked increase in size similar to that seen in normal blastocysts at the time of implantation. Implantation occurred when ovariectomy was performed on Day 10 p.c., but resorption followed immediately.

Immediate regressive changes were seen in uterine cornua of animals ovariectomized on Day 4 p.c. When ovariectomy was performed later, there was continued histological differentiation of the endometrium and some cornual growth. Cornua from animals ovariectomized on Day 6 p.c. were smaller than normal but were histologically similar to cornua from intact animals until about Day 20 p.c., after which regressive changes were found. Cornua from animals ovariectomized on Days 8 and 10 p.c. showed definite, albeit subnormal, growth in size after ovariectomy but exhibited essentially the same degree of histological development as normal cornua until Day 25 p.c.

It is suggested that the ferret uterus, once stimulated by ovarian hormones, is capable of prolonged response without further stimulus.

\section{INTRODUCTION}

Ovariectomy after implantation usually terminates pregnancy; although in some species, once a certain stage of development is attained, development may continue in the absence of the ovaries (Deanesly, 1966). On the other hand, various responses are observed following ovariectomy during the pre-implantation phase of pregnancy. Blastocysts degenerate before the time of implantation in the hamster (Orsini, 1963) and rabbit (Corner, 1928; Adams, 1958); however, if ovariectomy is performed while the conceptuses are still in the oviduct, degeneration does not occur until they enter the uterus. In rabbits ovariectomized immediately before nidation, a few blastocysts survive and while implantation is prevented, some embryonic development occurs (LutwakMann, Hay \& Adams, 1962).

* Present address: Department of Anatomy, Medical College of Ohio at Toledo, P.O. Box 6190, Toledo, Ohio 43614, U.S.A. 
Blastocysts remain in the uteri of ovariectomized rats for several days beyond the expected time of implantation, but there are conflicting data concerning their viability. Cochrane \& Meyer (1957) and Meyer \& Nutting (1964) could not induce implantation unless progesterone was administered from the time of ovariectomy. In contrast, Canivenc \& Laffargue (1957) obtained implants in $63 \%$ of their animals when hormones were not given until 7 days after ovariectomy and $45 \%$ implanted even if no hormones were given until 10 days afterwards. The disparity of these results may be due to strain differences or the fact that ovariectomy was performed on different days after mating. Smithberg \& Runner (1956, 1960), using prepuberal mice made sexually competent with gonadotrophins, showed that ovariectomy prevented implantation. However, blastocysts were retained for as long as 46 days and could be induced to implant if oestrogen and progesterone were given before the 32nd day. Bloch (1965) ovariectomized adult mice during lactation-induced delayed implantation and obtained nidation in nine of twenty-six animals when hormone injections were begun 4 to 9 days after ovariectomy. On the other hand, implantation occurred in only two of eighteen non-lactating mice ovariectomized on the 3rd, 4th or 5 th days of pregnancy when hormone therapy was started 3 to 7 days later.

Implantation occurs in three species following ovariectomy, but the postimplantation sequelae are quite different. Buchanan, Enders \& Talmage (1956) showed that ovariectomy of nine-banded armadillos during delayed implantation caused precocious implantation. The blastocysts implant 18 to 20 days post-operatively (Enders, 1966) and embryonic and foetal development proceed normally (Enders \& Buchanan, 1959). Loeb \& Hesselberg's observation (1917) that implantation is not prevented in guinea-pigs if ovariectomy is performed more than $48 \mathrm{hr}$ post coitum (p.c.) was confirmed and amplified by Deanesly (1960). Development is normal until about the 14th day, at which time resorption occurs unless exogenous hormones are given. The quokka, Setonix brachyurus, does not implant if ovariectomized during lactation-induced delayed implantation or within 2 days after removal of the pouch young, but the blastocyst persists for a long time. Ovariectomy performed more than 2 days after pouch young removal does not prevent implantation; however, the young achieve term only if the operation is performed 7 or more days afterward (Tyndale-Biscoe, 1963). Hartman (1925) reported that ovariectomizing pregnant opossums, Didelphis marsupialis, caused embryonic death. Gareful examination of Hartman's data shows that while ovariectomy during early embryonic differentiation caused prompt resorption, embryonic development continued for several days if the ovaries were removed while the conceptuses were at the blastocyst stage. Ovariectomy late in pregnancy, while preventing parturition, did not cause death of the embryos.

No systematic study of the effect of pre-implantation ovariectomy has been conducted with carnivores and the relevant papers in the literature contain data from very few animals (cat-Courrier \& Gros, 1935; dog-Marshall \& Jolly, 1906; badger-Canivenc \& Laffargue, 1958; Neal \& Harrison, 1958). Ferrets are unstudied altogether except for a single report (McPhail, 1935) which noted that two animals ovariectomized on Day 35 p.c. experienced premature parturition 3 to 5 days later. 
The diverse responses to ovariectomy during early pregnancy which occur in other mammals and the paucity of information concerning its effect in carnivores prompted the present study. Moreover, most mustelids exhibit delayed implantation and it was hoped that the information gained would be of comparative value in studies on other species. Preliminary results (Buchanan, 1964) suggested that while implantation was prevented, blastocyst survival and uterine changes varied depending on the time of ovariectomy.

\section{MATERIALS AND METHODS}

The material studied consisted of uterine cornua from thirty-five adult female ferrets which were divided into five experimental groups as follows: Group 1, four unmated ovariectomized animals; Group 2, six animals ovariectomized on Day 4 p.c.; Group 3, eleven animals ovariectomized on Day 6 p.c.; Group 4, nine animals ovariectomized on Day 8 p.c.; Group 5, five animals ovariectomized on Day 10 p.c. All animals were in oestrus at the beginning of the experiment and, excepting Group 1, were mated with fertile males, the day of mating being designated Day 0.

Animals were anaesthetized with sodium pentobarbital $(36 \mathrm{mg} / \mathrm{kg}$ intraperitoneally in a volume of $2 \mathrm{ml}$ ) and ovariectomy was performed under a binocular dissecting microscope. Each ovary was drawn to the surface of a dorsolateral incision by gentle traction on the upper mesometrium. A slit was made in the ovarian bursa well away from the oviduct and the bursa reflected away from the ovary. The ovarian stalk was clamped with a fine haemostat, ligated and severed. The reproductive tract was allowed to slip back into the abdominal cavity and the muscles and skin were closed separately with interrupted silk sutures.

Hemi-hysterectomies were performed at appropriate intervals following ovariectomy through a midventral incision. The cornu to be removed was ligated at the junction with the corpus uteri and a clamp placed immediately proximal to the ligature. The cornu was transected between clamp and ligature, rapidly freed from the mesometrium, laid on bibulous paper and photographed with a colour camera mounted over the operating table. Unimplanted cornua were flushed with normal saline and all cornua were divided into segments which were placed in a variety of fixatives for subsequent microscopic studies. The order of fixation and the segment placed in a particular fixative was the same in each case. The ovarian bursa and adjacent tissue were examined carefully under a dissecting microscope for possible ovarian remnants. Since a previous study (Buchanan, 1966) showed that hemi-hysterectomy did not affect pregnancy in the contralateral cornu, the results have been expressed in terms of cornua studied, and individual animals have not been identified.

For histological examination, Zenker's fixed material was stained in Masson's haematoxylin-ponceau-fuchsin-light green (Carleton \& Drury, 1957) and haematoxylin-eosin. Serra's fixed material was stained by the Feulgen technique (Carleton \& Drury, 1957) to reveal nuclear shape and obtain mitotic counts, and with eosin-methylene blue at $\mathrm{pH} 4.5$ (Burgos \& Wislocki, 1956) for cytoplasmic basophilia as well as general histological appearance. 
Uterine washings were examined under a compound microscope and the conceptuses counted, measured and, when possible, photographed.

\section{RESULTS}

\section{Effect of ovariectomy on implantation}

Table 1 shows the times of removal and the contents of uterine cornua removed from Groups 2, 3, 4 and 5. Uterine contents were rated as to stage of development and whether or not they showed signs of degeneration, based upon comparison with conceptuses recovered from intact unimplanted ferrets. One difficulty in assessing the condition of the conceptuses is the frequent occurrence of parthenogenetic cleavage in unfertilized ova which has been reported upon by Chang (1957). Such ova often have a coating of cells, presumably corona radiata, adherent to the zona pellucida and consist of a few unequal cellular masses fitting loosely in the zona. In other cases, especially when the outer covering of cells is absent, they may look quite like normal morulae. In Table 1, 'conceptuses' which were not clearly morulae or blastocysts have been listed as parthenogenetic ova. Blastocysts with a diameter exceeding $200 \mu$ were judged to have begun pre-implantation expansion and have been referred to as 'expanded blastocysts'.

Ovariectomy on Day 4 p.c. prevented implantation and, except in one instance, blastocyst expansion. However, most conceptuses recovered up to Day 15 p.c. did not show signs of degeneration. Cornua removed from Day 20 p.c. onward from Group 2 animals contained degenerating blastocysts, the degree of degeneration varying from blastocysts in which a few cells showed pyknosis, to zonae pellucidae containing mostly cellular debris.

Ovariectomy on Days 6 or 8 p.c. likewise prevented implantation but the fate of the conceptuses was somewhat different. Although several cornua removed on or before Day 15 p.c. did not contain conceptuses, most blastocysts which were recovered had undergone some degree of expansion. Blastocysts recovered from ferrets ovariectomized on Day 8 p.c. were more advanced and extremely large blastocysts were obtained from two cornua. A cornu removed on Day 11 p.c. contained a parthenogenetic ovum or degenerating morula, an unexpanded blastocyst and four blastocysts ranging in size from 1500 to $1900 \mu$ in diameter. A cornu removed on Day 15 p.c. (from a different animal) contained blastocysts of 733 and $1022 \mu$ diameters. In both instances, zonae pellucidae were still present although greatly attenuated. Most cornua removed from ferrets in Groups 3 and 4 on or after Day 20 p.c. were empty and conceptuses, when present, were usually degenerating.

Cornua removed on Days 13 and 15 p.c. from ferrets ovariectomized on Day 10 p.c. did not appear implanted and unexpanded blastocysts were recovered from the uterine flushings. A cornu removed on Day 20 p.c., on the other hand, had the typical appearance seen in uteri undergoing resorption. The entire cornu was intensely hyperaemic and darkly coloured and bore four small but distinct swellings. Histological examination of the swellings revealed leucocytic infiltration and much cellular debris in the lumen. Cornua removed later were similar in appearance except that distinctly swollen areas were not always seen. Areas of more intense vascularity were seen, however. 


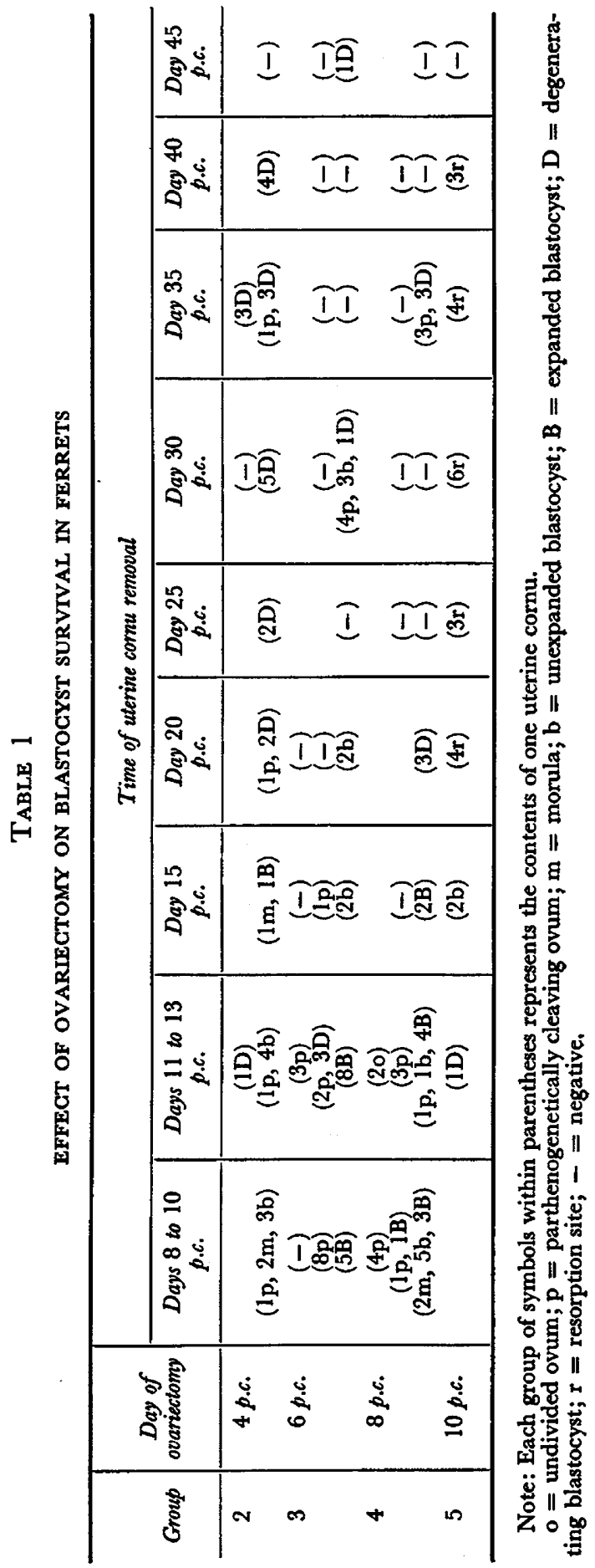


Gross changes in uterine cornua following ovariectomy

Table 2 compares the gross appearance of cornua from the various groups of ovariectomized animals with cornua from intact animals. Cornua removed during the first 10 days p.c. from normal pregnant and pseudopregnant ferrets did not differ in size and appearance from cornua of oestrous animals. Cornual elongation began during the latter part of the pre-implantation period and

TABLE 2

GROSS GHANGES IN FERRET CORNUA FOLLOWING OVARIECTOMY

\begin{tabular}{|c|c|c|c|c|c|c|c|}
\hline $\begin{array}{l}\text { Time of } \\
\text { cornu } \\
\text { removal }\end{array}$ & $*$ & $\begin{array}{l}\text { Control } \\
\text { group } \dagger\end{array}$ & $\begin{array}{c}\text { Group } \\
1\end{array}$ & $\begin{array}{c}\text { Group } \\
2\end{array}$ & $\begin{array}{c}\text { Group } \\
\mathbf{3}\end{array}$ & $\begin{array}{c}\text { Group } \\
4\end{array}$ & $\begin{array}{c}\text { Group } \\
5\end{array}$ \\
\hline Days 4 to 10 p.c. & $\begin{array}{c}\text { (No.) } \\
1 \\
w \\
\% \\
h\end{array}$ & $\begin{array}{c}(7) \\
60 \\
3 \cdot 2-2 \cdot 9 \\
65 \\
+\end{array}$ & $\begin{array}{c}(1) \\
48 \\
2 \cdot 3-2 \cdot 2 \\
55 \\
+\end{array}$ & $\begin{array}{c}(1) \\
49 \\
2 \cdot 8-2 \cdot 1 \\
59 \\
+\end{array}$ & $\begin{array}{c}(2) \\
59 \\
2 \cdot 9-2 \cdot 2 \\
65 \\
++\end{array}$ & $\begin{array}{c}(3) \\
57 \\
3 \cdot 5-2 \cdot 9 \\
64 \\
++\end{array}$ & \\
\hline Days 11 to 13 p.c. & $\begin{array}{c}\text { (No.) } \\
1 \\
\mathbf{w} \\
\% \\
\mathbf{h}\end{array}$ & $\begin{array}{c}(4) \\
78 \\
3 \cdot 0-2 \cdot 8 \\
63 \\
+\end{array}$ & $\begin{array}{c}(1) \\
47 \\
2 \cdot 3-2 \cdot 0 \\
59 \\
++\end{array}$ & $\begin{array}{c}(2) \\
49 \\
2 \cdot 0-2 \cdot 0 \\
63 \\
+\end{array}$ & $\begin{array}{c}(3) \\
46 \\
2 \cdot 5-1 \cdot 9 \\
63 \\
+\end{array}$ & $\begin{array}{c}(2) \\
49 \\
2 \cdot 8-2 \cdot 6 \\
62 \\
++\end{array}$ & $\begin{array}{c}(1) \\
50 \\
2 \cdot 7-2 \cdot 6 \\
74 \\
+++\end{array}$ \\
\hline Day 15 p.c. & $\begin{array}{c}\text { (No.) } \\
1 \\
w \\
\% \\
h\end{array}$ & $\begin{array}{c}(2) \\
106 \\
3 \cdot 2-2 \cdot 4 \\
69 \\
+++\end{array}$ & $\begin{array}{c}(1) \\
50 \\
1 \cdot 7-2 \cdot 0 \\
65 \\
\pm\end{array}$ & $\begin{array}{c}(1) \\
48 \\
2 \cdot 5-1 \cdot 7 \\
61 \\
++\end{array}$ & $\begin{array}{c}(3) \\
59 \\
2 \cdot 9-2 \cdot 3 \\
72 \\
+++\end{array}$ & $\begin{array}{c}(2) \\
68 \\
3 \cdot 3-2 \cdot 3 \\
69 \\
+++\end{array}$ & $\begin{array}{c}(1) \\
45 \\
2 \cdot 6-2 \cdot 3 \\
67 \\
+++\end{array}$ \\
\hline Days 20 to 25 p.c. & $\begin{array}{c}\text { (No.) } \\
\mathbf{l} \\
\mathrm{w} \\
\mathrm{o} \\
\mathrm{h}\end{array}$ & $\begin{array}{c}(6) \\
124 \\
4 \cdot 6-4 \cdot 2 \\
76 \\
+++\end{array}$ & $\begin{array}{c}(2) \\
52 \\
2 \cdot 0-1 \cdot 9 \\
63 \\
\pm\end{array}$ & $\begin{array}{c}(2) \\
50 \\
2 \cdot 3-1 \cdot 6 \\
68 \\
+\end{array}$ & $\begin{array}{c}(4) \\
46 \\
2 \cdot 4-2 \cdot 1 \\
66 \\
++\end{array}$ & $\begin{array}{c}(3) \\
53 \\
3 \cdot 2-2 \cdot 7 \\
80 \\
+++\end{array}$ & $\begin{array}{c}(2) \\
54 \\
3 \cdot 3-2 \cdot 6 \\
70 \\
+++\end{array}$ \\
\hline Days 30 to 45 p.c. & $\begin{array}{c}\text { (No.) } \\
1 \\
w \\
\% \\
h\end{array}$ & $\begin{array}{c}(3) \\
90 \\
4 \cdot 5-3 \cdot 6 \\
80 \\
++\end{array}$ & & $\begin{array}{c}(6) \\
49 \\
2 \cdot 0-1 \cdot 5 \\
67 \\
+\end{array}$ & $\begin{array}{c}(8) \\
46 \\
1 \cdot 9-1 \cdot 6 \\
68 \\
+\end{array}$ & $\begin{array}{c}(7) \\
52 \\
2 \cdot 3-1 \cdot 8 \\
68 \\
++\end{array}$ & $\begin{array}{c}(4) \\
57 \\
2 \cdot 4-1.9 \\
68 \\
++\end{array}$ \\
\hline
\end{tabular}

* No. = number of cornua; $1=$ mean cornu length in $\mathrm{mm} ; \mathrm{w}=$ mean cornu diameters in $\mathrm{mm}$ (first number $=$ mesometrial-antimesometrial axis, second number $=$ transverse axis); $\%=$ percentage of diameter represented by endometrium; $h=$ hyperaemia $(t=$ moderate, $+++=$ intense).

$\dagger$ Control group comprised of normal pregnant and pseudopregnant animals up to and including Day 15 p.c., thereafter of pseudopregnant animals only.

continued until about the middle of the gestation period. However, increased diameter, and increases in the amount of endometrium were not seen until implantation.

Immediate regressive changes were seen in cornua from unmated ovariectomized ferrets (Group 1). Although decreases in size were slight beyond Day 13 p.c., cornua were quite flaccid and scarcely hyperaemic. Cornua from animals ovariectomized on Day 4 p.c. (Group 2) likewise showed prompt regression and 
differed from Group 1 only in that they were slightly larger and did not become flaccid until after Day 20 p.c.

Except for a failure to increase in length, cornua from Group 3 appeared normal until after Day 15 p.c. Actually some growth occurred, since in several animals the second cornu removed was longer than the first. However, the variation between animals was such that the increase could not be considered significant. An increased amount of endometrium and an intense hyperaemia were seen in cornua removed on Day 15 p.c. but thereafter regressive changes were obvious.

In Group 4, there was definite post-operative growth. The cornua removed on Day 15 p.c. were 10 to $15 \mathrm{~mm}$ longer than cornua removed earlier, had an increased amount of endometrium and were intensely hyperaemic. Although length decreased after Day 15 p.c., diameter was maintained and the amount of endometrium actually increased until after Day 25 p.c.

Cornua from Group 5 (in which there was implantation and resorption) did not change in gross appearance throughout the experimental period.

\section{Histological changes in the endometrium following ovariectomy}

Group 1 (unmated ovariectomized animals). Prompt endometrial regression was seen following ovariectomy. The luminal epithelium, which at oestrus had been tall columnar, was columnar to low columnar 5 days after ovariectomy and by 25 days afterward, most cells were cuboidal with a scanty cytoplasm (Pl. 1, Fig. 1). The virtual absence of apical mucus, the thin, poorly-stained brush border, and the lack of any significant cytoplasmic basophilia indicated a lack of secretory activity. Uterine glands likewise declined so that by 25 days after ovariectomy, only a few very short, straight and non-dilated glands remained. Gland cells, like luminal cells, showed no evidence of secretory activity.

Group 2 (ovariectomized on Day 4 p.c.). The endometria of this group regressed in basically the same fashion as was seen in Group 1 (Pl. 1, Fig. 2). A few differences were noted, especially in cornua removed shortly after ovariectomy, which were undoubtedly due to the brief influence of the corpus luteum. Most uterine glands were slightly dilated, but a few (two to four per section) were greatly dilated. Although these greatly dilated glands decreased in size as the endometrium regressed, they never disappeared. Additionally, the gland cells showed a moderate basophilia up to Day 25 p.c. and variable amounts of secretory material were seen in the glandular lumina. Although mitoses were never seen in cornua from unmated ovariectomized ferrets, occasional mitotic figures (one or two per ten sections examined) were seen in the luminal epithelia of cornua removed 25 to 35 days p.c. from Group 2 animals.

Group 3 (ovariectomized on Day 6 p.c.). Continued endometrial development occurred in this group and up to Day 20 p.c., the cornua were histologically similar to corresponding material from normal pregnant animals (see Buchanan, 1966). By Day 13 p.c., the tall columnar luminal epithelium was crowded and exhibited some areas of pseudostratification. Uterine glands were elongated with some basal coiling. Gland necks were slightly dilated, gland fundi were moderately dilated, and a few fundi (five to ten per section) were greatly dilated. Both luminal and gland cells had distinct brush borders, moderate 
cytoplasmic basophilia and secretory material adherent to the apical portions of the cells. Secretory material was present in the glandular lumina, especially the fundic portions. Occasional mitotic figures were seen in the epithelial cells.

Pre-symplasm formation (see Buchanan, 1966), involving the luminal epithelium and gland necks, was seen in one of three cornua removed on Day 15 p.c. and in two of three cornua removed on Day 20 p.c. (Pl. 1, Fig. 3). Much secretory material was present in the central and glandular lumina. Mitoses were common in the cornu removed on Day 15 p.c., especially in the glands immediately below the pre-symplasm. However, only occasional mitoses were noted in the two pre-symplasmic cornu removed on Day 20 p.c. The third cornu removed on Day 20 p.c. was regressing. The epithelium was much reduced and there was little evidence of secretory activity.

Most cornua removed on Day 25 p.c. and afterwards were regressing (Pl. 1, Fig. 4), but secretory material was still present in the glandular lumina and occasional mitoses were seen. One cornu removed on Day 35 p.c. had a presymplasmic luminal epithelium and glands which were secretory. Another cornu, removed on Day 40 p.c., contained numerous mitotic figures and had the histological appearance of an oestrous cornu. In both cases, searches for residual ovarian tissue were negative.

Group 4 (ovariectomized on Day 8 p.c.). Development continued after ovariectomy in this group also. Both the luminal epithelium and gland necks were pre-

\section{EXPLANATION OF PLATE 1}

All tissues were fixed in Serra's fiuid and stained by the Feulgen technique with light green counterstain. $\times 165$.

FIG. 1. Endometrium of an unmated oestrous animal 25 days after ovariectomy. Luminal epithelium is cuboidal with scanty, poorly stained cytoplasm. Glands are short, straight and non-dilated. Gland cells are low columnar with scanty cytoplasm.

Frg. 2. Endometrium removed on Day 25 p.c. from an animal ovariectomized on Day 4 p.c. The endometrium is essentially like that in Fig. 1 with a cuboidal luminal epithelium and short straight glands composed of low columnar cells. Small amounts of secretory material are present in the gland lumina.

FIG. 3. Endometrium removed on Day 20 p.c. from an animal ovariectomized on Day 6 p.c. Luminal epithelium and gland necks show pre-symplasm. Glands are moderately dilated, show basal coiling and contain secretory material in the lumina.

Fig. 4. Endometrium removed on Day 25 p.c. from an animal ovariectomized on Day 6 p.c. Luminal epithelium is cuboidal with scanty cytoplasm. Glands are non-dilated and generally straight with low columnar cells and secretory material in the lumina. Moderate numbers of granule-laden macrophages are present in the stroma. Compare with Figs. 1 and 2.

FrG. 5. Endometrium removed on Day 20 p.c. from an animal ovariectomized on Day 8 p.c. Luminal epithelium and gland necks exhibit pre-symplasm. Secretory material is present on the luminal surface and in the lumina of the greatly enlarged glands.

Fig. 6. Endometrium removed on Day 25 p.c. from an animal ovariectomized on Day 8 p.c. Luminal epithelium and glands, except the fundic portions, exhibit pre-symplasm. Lumina of gland fundi contain secretory material and symplasmic masses. Mitoses (arrows) are present in the lower portion of some glands.

FIG. 7. Endometrium removed on Day 25 p.c. from an intact pregnant animal. The luminal epithelium and gland necks show extensive pre-symplasm development. The stroma is compressed into thin laminae.

Fic. 8. Endometrium removed on Day 25 p.c. from an animal ovariectomized on Day 10 p.c. The luminal epithelium and gland necks show extensive pre-symplasm development. Secretory material is adherent to the luminal surface and in the gland lumina. Necrotic material and symplasmic masses are present in the central lumen. 


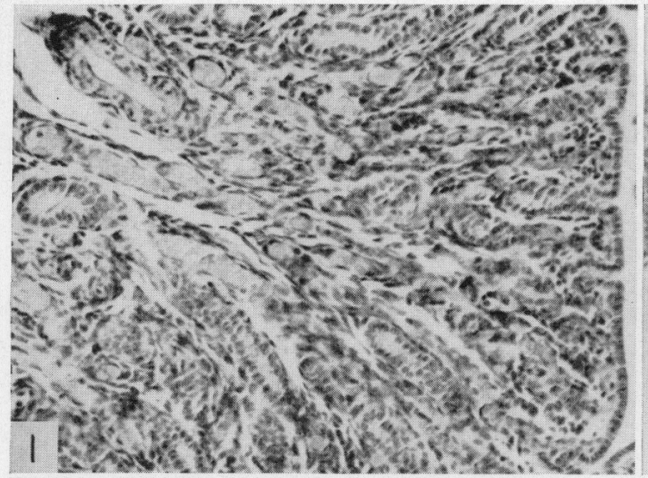

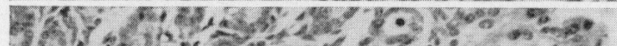

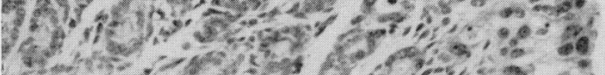

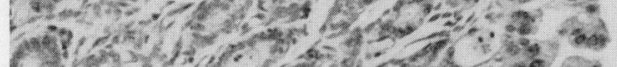

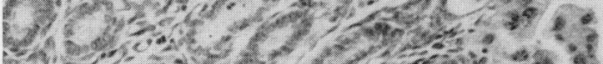

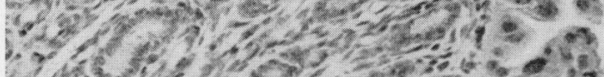

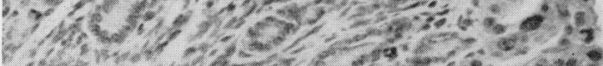

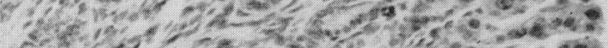

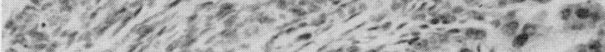

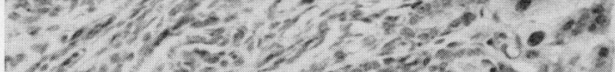

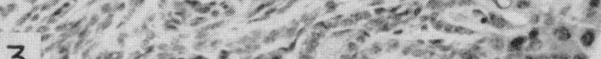

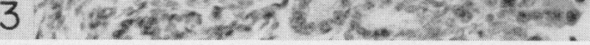

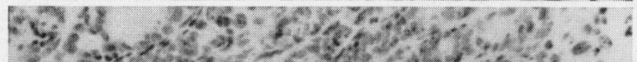

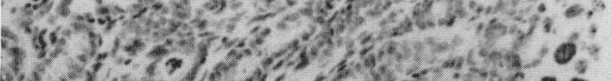
-

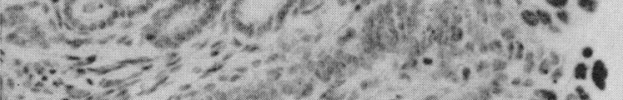
4 - 3 -

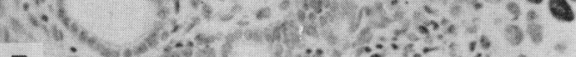

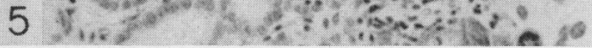
78

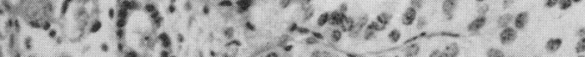

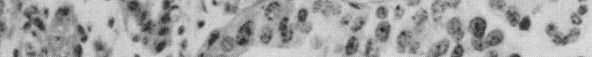
i. -

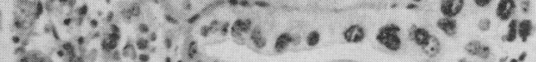

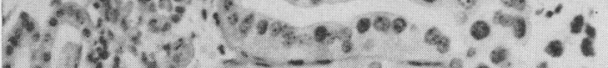

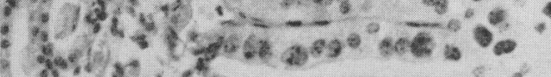

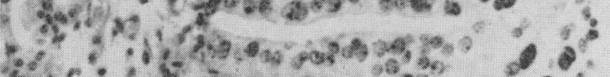

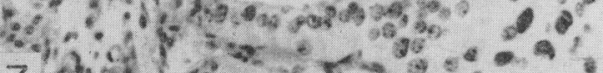
7 की

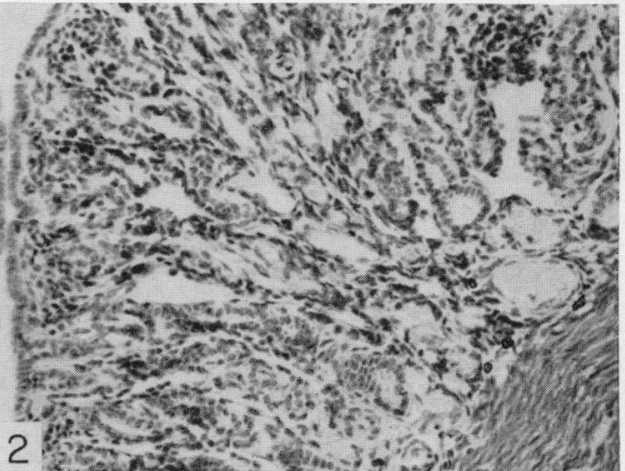

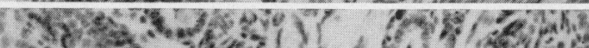

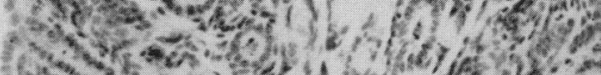

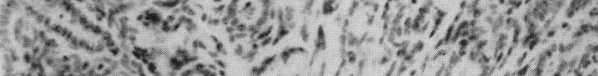
?.3.

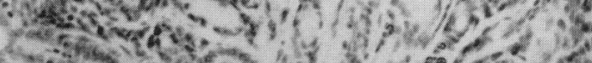

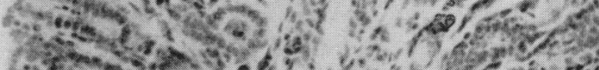

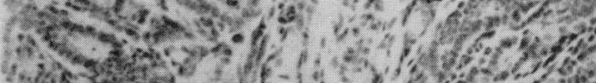
2. 1.

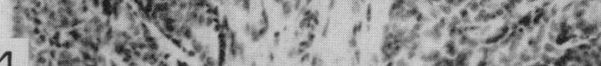
4 Fin.

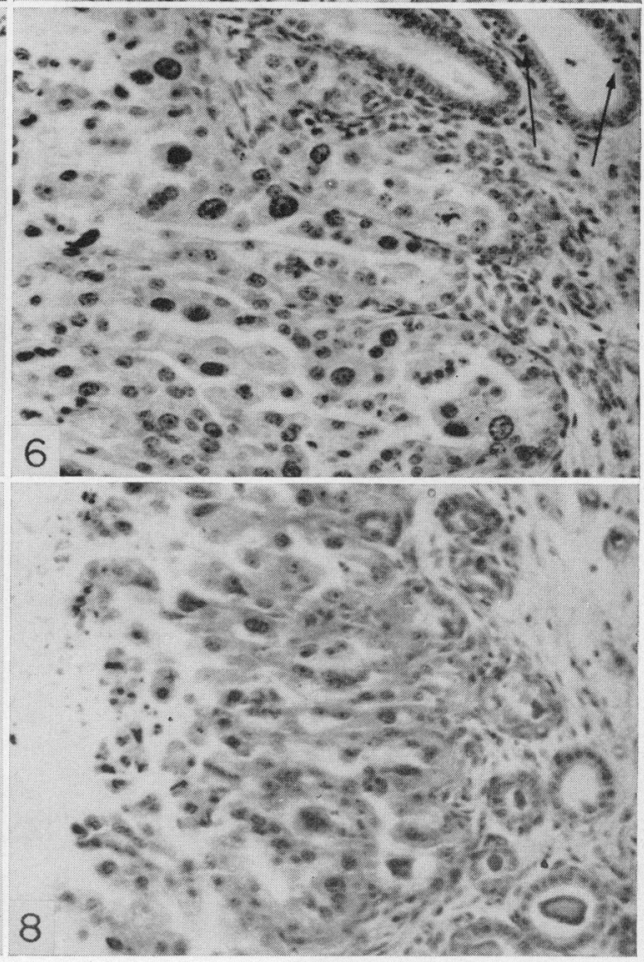

(Facing p. 312) 
symplasmic in cornua removed on Days 20 and 25 p.c. (P1. 1, Figs. 5 and 6), and the general appearance did not differ significantly from corresponding cornua of intact animals (Pl. 1, Fig. 7). The uterine glands were much enlarged and filled with secretory material. Symplasmic masses were present in the lumina of the glands of cornua removed on Day 25 p.c. (Pl. 1, Fig. 6). Mitoses were common in the lower portions of the glands.

Some regression was evident in cornua removed on Day 30 p.c. One cornu had a columnar luminal epithelium, whereas the contralateral cornu had exhibited pre-symplasm when removed earlier. Another cornu, likewise, had a columnar epithelium. However, the gland fundi were greatly dilated and filled with symplasmic masses. Additionally, several 'cysts' of pre-symplasm were seen in the area spongiosa. These probably represent invaginations of the luminal epithelium such as have been described in normal pregnant and pseudopregnant animals (Buchanan, 1966). Mitoses were numerous in the gland cells but scarce in the luminal epithelium. One cornu removed on Day 35 p.c. showed extensive pre-symplasm and symplasm formation, but all other cornua removed after Day 30 p.c. were regressing.

Group 5 (ovariectomized on Day 10 p.c.) The histological appearance of cornua from this group (Pl. 1, Fig. 8) was similar in all respects to correspondingly timed material from the preceding group. The central lumen contained somewhat more secretory material, but this was most likely owing to the fact that these cornua were not flushed for blastocysts. Perhaps the greatest difference between these cornua and those of Group 4 was that regression seemed to begin more gradually and at a slightly later stage. The cranial portion of the cornu removed at 25 days p.c. did not exhibit pre-symplasm. However, the endothelium of the capillaries was greatly hypertrophied, reminiscent of the pattern seen adjacent to the placenta in pregnant animals. Uterine cornua removed on Days 30 and 35 p.c. had scattered regions of pre-symplasm and symplasm. As in corresponding material from Group 4, cysts of pre-symplasm and symplasm were scattered throughout the stroma. Cornua removed on Days 40 and 45 p.c. had columnar or tall columnar luminal epithelia. The glands were short but not so short as those in other groups.

\section{DISGUSSION}

These data show that successful implantation in the ferret requires the presence of the ovaries. A similar situation appears to obtain in the cat since ovariectomy between $30 \mathrm{hr}$ and 11 days after mating was reported to prevent implantation (Courrier \& Gros, 1935). Data of Marshall \& Jolly (1906) suggest that the same is true in the bitch. In three animals ovariectomized on Days 3, 10 and 14 p.c., respectively, the first never became visibly pregnant and pregnancy did not continue in the others, although swellings were visible on the uteri at the time of operation.

The ability of ferret blastocysts to survive for a brief time in the absence of the ovaries resembles somewhat the situation in ovariectomized rats and mice in which blastocysts also persist for a while beyond the time at which implantation should occur (Canivenc \& Laffargue, 1957; Smithberg \& Runner, 1960). 
However, degeneration of ferret blastocysts begins between Days 15 and 20 p.c. regardless of the day of ovariectomy; whilst, in rats, the duration of blastocyst survival varies with the time of ovariectomy (unpublished observations).

The post-operative development of ferret blastocysts, on the other hand, is related to the day of ovariectomy. Thus, while ovariectomy on Day 4 p.c. prevents expansion, blastocysts from ferrets ovariectomized on Day 6 p.c. or later continue to grow and an increase in size occurs which is characteristic of implanting carnivore blastocysts. Although some of the expanded blastocysts were probably fixed within the uterus as a result of their expansion, implantation in the sense of a reaction between endometrium and trophoblast did not occur except as a transitory phenomenon in animals ovariectomized on Day 10 p.c. In these animals, one can suppose that implantation changes were already under way at the time of ovariectomy and that initial attachment took place in spite of the operation. It should be noted, however, that resorption sites were first seen on Day 20 p.c. and it is tempting to speculate on whether or not the implantation reaction was delayed.

The only relevant data from other carnivores concerns species with delayed implantation. Wright (1963) found dead blastocysts in the uterus of a weasel, Mustela frenata, 16 days after ovariectomy. Since the uterus showed signs of regression, he felt that the ovaries were essential for maintaining the blastocysts. On the other hand, Canivenc \& Laffargue (1958) ovariectomized four European badgers early in the delay period and observed no changes in either the blastocysts or the uteri when autopsies were performed 6,23 or 28 days later. Neal \& Harrison (1958) recovered greatly enlarged blastocysts from a single badger which had been ovariectomized 10 weeks earlier. Although this animal was killed in November when the blastocysts of intact animals were undergoing enlargement preparatory to nidation, the blastocysts from the ovariectomized animal were more than twice the size of normal blastocysts. The descriptions and figures of these blastocysts are quite similar to the greatly enlarged blastocysts recovered from some ferrets in this study, and it is suggested that mustelid blastocysts are capable of undergoing implantation changes in the absence of ovarian hormones. The failure of the enlarged blastocysts to implant in the case of the badger is understandable since the endometrium did not look progestational. This was not true, however, in the ferret and it is possible that implantation was prevented by the persistent zona pellucida, the loss of which is probably progesterone-dependent.

The continued histological differentiation and growth seen in the uteri of ovariectomized ferrets in Groups 3 and 4 was surprising since prompt regressive changes have been noted in the uteri of other species in which ovariectomy prevents implantation (e.g. hamster, rabbit, rat, mouse, cat). The failure of the endometrium of animals ovariectomized on Day 4 p.c. to develop suggests that progesterone is necessary to initiate such changes. However, it is difficult to believe that a residuum of circulating hormones was present to sustain endometrial growth for 3 weeks. The prompt regression of the uteri of non-mated ovariectomized animals argues against the presence of any significant non-ovarian source of female hormones. It is suggested that once progestational changes have been initiated in the uterus, they can continue without further hormonal 
stimulus. Tyndale-Biscoe (1963) has made a similar suggestion in the case of the quokka.

\section{ACKNOWLEDGMENTS}

The author is grateful to Maxi Archibald and Lynn B. Goldner who provided invaluable technical assistance in preparation of tissues and in animal surgery. This investigation was supported by Public Health Service Grant number HD-00504, from the National Institute of Child Health and Human Development.

\section{REFERENCES}

AdAms, C. E. (1958) Egg development in the rabbit. The influence of post-coital ligation of the uterine tube and of ovariectomy. 7. Endocr. 16, 283.

BLoch, S. (1965) Beobachtung über den Einfluss der Laktation auf die Erhaltung der Blastocysten bei kastrierten Mäusen. Experientia, 21, 443.

Buchanan, G. D. (1964) Some effects of pre-implantation ovariectomy in ferrets. Tex. Rep. Biol. Med. 22,210 .

Buchanan, G. D. (1966) Reproduction in the ferret (Mustela furo). I. Uterine histology and histochemistry during pregnancy and pseudopregnancy. Am. 7. Anat. 118, 195.

Buchanan, G. D., Enders, A. C. \& TAlmage, R. V. (1956) Implantation in armadillos ovariectomized during the period of delayed implantation. F. Endocr. 14, 121.

BURgos, M. H. \& WisLockI, G. B. (1956) The cyclic changes in the guinea pig's uterus, cervix, vagina and sexual skin, investigated by histological and histochemical means. Endocrinology, 59, 93.

Ganivenc, R. \& Laffargue, M. (1957) Survie des blastocystes du rat en l'absence d'hormones ovariennes. C. r. hebd. Séanc. Acad. Sci., Paris, 245, 1752.

Canivenc, R. \& Laffargue, M. (1958) Action de différents équilibres hormonaux sur la phase de vie libre de l'œuf fécondé chez le blaireau européen (Meles meles L.). C. r. Séanc. Soc. Biol. 152, 58.

Carleton, H. M. \& Drury, R. A. B. (1957) Histological technique, 3rd edn., pp. 106, 144. Oxford University Press, London.

Chang, M. C. (1957) Natural occurrence and artificial induction of parthenogenetic cleavage of ferret ova. Anat. Rec. 128, 187.

Cochrane, R. L. \& Meyer, R. K. (1957) Delayed nidation in the rat induced by progesterone. Proc. Soc. exp. Biol. Med. 96, 115.

Corner, G. W. (1928) Physiology of the corpus luteum. I. The effect of early ablation of the corpus luteum upon embryos and uterus. Am. 7. Physiol. 86, 74.

Courrier, R. \& Gros. G. (1935) Contribution à l'endocrinologie de la grossesse chez la chatte. C. r. Séanc. Soc. Biol. $120,5$.

DEANESLY, R. (1960) Implantation and early pregnancy in ovariectomized guinea-pigs. F. Reprod. Fert. $1,242$.

DeAnesLy, R. (1966) The endocrinology of pregnancy and foetal life. In: Marshall's Physiology of Reproduction, 3rd edn., vol. 3, p. 891. Ed. A. S. Parkes. Longmans Green, London.

Enders, A. C. (1966) The reproductive cycle of the nine-banded armadillo (Dasypus novemcinctus). Symp. zool. Soc. Lond. 15, 295.

Enders, A. G. \& Buchanan, G. D. (1959) Some effects of ovariectomy and injection of ovarian hormones in the armadillo. F. Endocr. 19, 251.

Harmman, C. G. (1925) The interruption of pregnancy by ovariectomy in the aplacental opossum: A study in the physiology of implantation. Am. F. Physiol. 71, 436.

Loeb, L. \& Hesselberg, G. (1917) The cyclic changes in the mammary gland under normal and pathological conditions. Part II. F. exp. Med. $25,305$.

Lutwak-Mann, G., Hay, M. K. \& Adams, C. E. (1962) The effect of ovariectomy on rabbit blastocysts. 7. Endocr. 24, 185.

McPhaIL, M. K. (1935) Studies on the hypophysectomized ferret. IX. The effect of hypophysectomy on pregnancy and lactation. Proc. $R$. Soc. B, 117, 34.

Marshall, F. H. A. \& Jolly, W. A. (1906) Contributions to the physiology of mammalian reproduction. Part II: The ovary as an organ of internal secretion. Phil. Trans. R. Soc. B, 198, 123.

MeYer, R. K. \& NutTing, E. F. (1964) Effect of combinations of progesterone and oestrone on the delay of nidation, implantation and foetal survival in ovariectomized rats. F. Endocr. 29, 243. 
Neal, E. G. \& Harrison, R. J. (1958) Reproduction in the European badger (Meles meles L.). Trans. zool. Soc. Lond. 29, 67.

Orsint, M. W. (1963) Morphological evidence on the intrauterine career of the ovum. In: Delayed Implantation, p. 155. Ed. A. C. Enders. University of Chicago Press.

SmithBerg, M. \& RunNer, M. N. (1956) The induction and maintenance of pregnancy in prepuberal mice. F. $\exp$. Zool. 133, 441.

Smrthberg, M. \& RunNer, M. N. (1960) Retention of blastocysts in non-progestational uteri of mice. 7. exp. Zool. 143, 21.

Tyndale-Biscor, C. H. (1963) Effects of ovariectomy in the marsupial Setonix brachyurus. F. Reprod. Fert. $6,25$.

WRIGHT, P. L. (1963) Variations in reproductive cycles in. North American mustelids. In: Delayed Implantation, p. 77. Ed. A. C. Enders. University of Chicago Press 